Harvard Studies in Business History • 52

Published with the support of the

Harvard Business School

EDITED BY

Walter A. Friedman

Lecturer of Business Administration

Director, Business History Initiative

AND

Geoffrey Jones

Isidor Straus Professor of Business History

Faculty Chair, Business History Initiative

Harvard Business School 



\section{RAILROADS AND THE TRANSFORMATION OF CHINA}

ELISABETH KÖLL

$\rightleftharpoons$

Harvard University Press

Cambridge, Massachusetts

London, England

2019 
Copyright $\odot 2019$ by the President and Fellows of Harvard College All rights reserved

Printed in the United States of America

First printing

Jacket design: Tim Jones

Jacket art: Illustrations of exterior and interior of a steam locomotive in Gezhi huibian, 1877

$$
\begin{gathered}
9780674916425 \text { (EPUB) } \\
9780674916432 \text { (MOBI) } \\
9780674916418 \text { (PDF) }
\end{gathered}
$$

The Library of Congress has cataloged the printed edition as follows:

Names: Köll, Elisabeth, 1965- author.

Title: Railroads and the transformation of China / Elisabeth Köll.

Other titles: Harvard studies in business history; 52.

Description: Cambridge, Massachusetts : Harvard University Press, 2019. |

Series: Harvard studies in business history; 52 | Includes

bibliographical references and index.

Identifiers: LCCN 2018014456 | ISBN 9780674368170 (hardcover : alk. paper)

Subjects: LCSH: Railroads-China-History. | Railroads and state-China-History. |

Infrastructure (Economics)-China.

Classification: LCC HE3288 .K65 2019 | DDC 385.0951-dc23

LC record available at https://lccn.loc.gov/2018014456 


\section{In memoriam Michael Quirin}


